J. Nepal Chem. Soc., Vol. 37, 2017

\title{
Antioxidant and Antifungal Potential of Bombax ceiba Bark Extract
}

\author{
Khaga Raj Sharma and Surya Kant Kalauni* \\ Central Department of Chemistry, Tribhuvan University, Kirtipur, Kathmandu, Nepal \\ Email:skkalauni@gmail.com
}

\begin{abstract}
Nepalese medicinal plants have been used since many years in different communities for treatment of different diseases. The aim of the present study is to explore the antioxidant and antifungal potential with total phenolic and flavonoid content in stem bark extract of Bombax ceiba collected from Chitwan district of Nepal. In developing countries medicinal plants are used as medicine for being high effectiveness and affordability. Mainly peoples who are living in rural areas using these medicinal plants as first line of treatment based on disease conditions. In the present work it is evaluated that the antioxidant and antifungal potential of methanol bark extract of Bombax ceiba. Antioxidant potential was determined by DPPH radical scavenging assay and antifungal activity was studied by agar well dilution protocol. The total phenolic and flavonoid content was determined by using Folin-Ciocalteu phenol reagent and aluminium chloride method. The $I C_{50}$ value for radical scavenging potential was found $9.37 \pm 0.12 \mu \mathrm{g} / \mathrm{mL}$ whereas ascorbic acid has $45.93 \mu \mathrm{g} / \mathrm{mL}$. Total phenolic content was $147.45 \pm 0.15 \mathrm{mg} \mathrm{GAE} / \mathrm{gm}$ and flavonoid content was $12.54 \pm 0.10 \mathrm{mg} Q E / \mathrm{gm}$. The sample showed moderate activity against Trichophyton subrum showed linear growth $55 \mathrm{~mm}$ with 45 percent inhibition as compared to standard drug Miconazole MIC $97.8 \mu \mathrm{g} / \mathrm{mL}$. This study revealed that Bombax ceiba has broad spectrum antifungal activity and it can provide defense against oxidative stress.
\end{abstract}

Keywords: antioxidant, antifungal, DPPH, Bombax ceiba, aluminium chloride

\section{Introduction}

People have been using medicinal plants since many years for the easy accessible and affordable source of medicine for treatment of different diseases. The rural people have a long history of traditional plant usage for medicinal purposes. About 80 percent of the population in developing countries used traditional medicines because they do not afford the high cost of western pharmaceuticals and traditional medicines are also more acceptable from a cultural and spiritual perspective ${ }^{1}$.

Bombax ceiba, locally known as Simal, is widely distributed in hilly and terai regions of Nepal. The plant is a large, briefly deciduous tree occurring in warm monsoon forests in southern Asia. The plant belongs to family Bombacaceae. It was collected from Chitwan district for the purpose of present study. It has been traditionally used for the treatment of diarrhea, burns and dysentery. Bombax ceiba is an important Ayurvedic medicinal plant found in Nepal, Pakistan, India, China and Australia ${ }^{2}$. Almost every part of this plant is used as medicine, and its roots and flowers are used for curing the maximum number

${ }^{*}$ Corresponding author 


\section{J. Nepal Chem. Soc., Vol. 37, 2017}

of ailments ${ }^{3}$. According to Ayurveda plant has great medicinal value and used for treatment of different ailments stimulant, hemostatic, antidiahorreal, antidysentric and antipyretic ${ }^{4,5}$. The bark is rich source of lupeol, saponins, tannins, gums and 4,5,7-trihydroxyflavone-3-O- $\beta$-D-glucopyranosyl(1-4)- $\alpha$-Lrhamnopyranoside ${ }^{6}$. Two new aromatic compounds were isolated from stem bark of Bombax ceiba along with five known compounds shamiminol, O-epicatechin-7-O- $\beta$-xylopyranoside, O-catechin-7-O- $\beta$ xylopyra- noside, $(+)$-isolarisiresinol-9-O- $\beta$-glucopyranoside and $(+)$ lyonires inol-9-O- $\beta$-glucopyranoside 7. Methanolic extract of the roots showed high amount of phenolic and tannins showing strong DPPH radical scavenging activity in a dose dependent manner ${ }^{8}$. Aqueous and ethanol bark extracts subjected in vitro antioxidant activity screening models ${ }^{9}$. previous researcher has reported the diuretic effects of aqueous and crude ethanol extract of Bombax ceiba L. fruits using acute model in rats. The aqueous and ethanol extract of Bombax ceiba fruit significantly increased the urine output in higher doses. These effects demonstrate possible diuretic actions and support its folklore use in various urinary ailments ${ }^{10}$.

Therefore, there is a need to study antioxidant and antifungal potential of phytoconstituents by determining total phenolic and flavonoid content in methanol bark extract of Bombax ceiba that help for developing the new drugs.

\section{Experimental Methods}

\section{Plant collection and authentication}

In the present study, the barks of Bombax ceiba were collected from Chitwan district of Nepal based on the ethnobotanical uses. The plant was authenticated by Rita Chhetry, Research Officer, National Herbarium and plant Resources, Ministry of Forests and Soil Conservation, Godawari Nepal and the voucher specimen was submitted to the same department.

\section{Extraction}

These barks of Bombax ceiba was shade dried at room temperature and powdered material was then weighed $(50.0 \mathrm{~g})$, soaked in methanol for $72 \mathrm{~h}$ and filtered. The filtrate was concentrated under reduced pressure in rotatory evaporator to obtain the crude extract.

\section{Phytochemical study}

The methanolic extract was analyzed for the presence of secondary metabolites such as polyphenols, alkaloids, flavonoids, tannins, carotenoids, saponins, reducing sugars, cardiac glycosides, steroids, terpenoids, and anthraquinone by adopted standard protocol ${ }^{11,12}$.

\section{DPPH radical scavenging assay}

The free radical scavenging assay was performed by adopting the standard protocol in which the concentration of test samples $(5,10,20,30,40,50,60,70,80,90,100 \mu \mathrm{g} / \mathrm{mL})$ was prepared while the concentration of DPPH was $0.2 \mathrm{mM}^{13,14,15}$. Reaction mixtures were taken in tubes and incubated at $37{ }^{\circ} \mathrm{C}$ for 30 minutes. Discolorations were measured at $517 \mathrm{~nm}$ using a UV-Visible spectrophotometer. Percent radical scavenging activity was determined by comparison with methanol treated control group; ascorbic acid was used as positive control. Measurement was performed at least in triplicate. The percentage scavenging of the DPPH free radical was calculated using the equation. The calibration curve was plotted for the triplicate experiments and represented as percentage of mean inhibition \pm standard deviation and the $\mathrm{IC}_{50}$ values were obtained. 


\section{Total phenolic content determination}

The total phenolic content was determined using the Folin-Ciocalteu phenol reagent. In which $0.1 \mathrm{~mL}$ of each extract $(2.5 \mathrm{mg} / \mathrm{mL})$ was separately mixed with $1 \mathrm{~mL}$ of Folin-Ciocalteu phenol reagent and 0.8 $\mathrm{mL}$ of aqueous $1 \mathrm{M} \mathrm{Na}_{2} \mathrm{CO}_{3}$ solution. The reaction mixture was allowed to stand for about 15 minutes and the absorbance of the reactants was measured at $765 \mathrm{~nm}$ using the UV-visible spectrophotometer. The calibration curve was constructed using gallic acid as standard for concentration ranging from 25-250 $\mu \mathrm{g} / \mathrm{mL}$. The concentration of the sample was calculated with the help of standard plot of gallic acid. The total polyphenol content was expressed in terms of the milligrams of the gallic acid equivalent per gram of the dry mass (mg GAE/g) $)^{16}$.

\section{Total flavonoid content determination}

The total flavonoid content was estimated by using the aluminium chloride $\left(\mathrm{AlCl}_{3}\right)$ colorimetric method. In this method, $0.25 \mathrm{~mL}$ extract $(10 \mathrm{mg} / \mathrm{mL})$ was separately mixed with the $0.75 \mathrm{~mL}$ of methanol, $0.05 \mathrm{~mL}$ of the $10 \%$ aluminum chloride, $0.05 \mathrm{~mL}$ of the $1 \mathrm{M}$ potassium acetate $\left(\mathrm{CH}_{3} \mathrm{COOK}\right)$ and $1.4 \mathrm{~mL}$ of the distilled water. The reaction mixture was allowed to stand for about 30 minutes at room temperature. The absorbance of the mixture was measured at $415 \mathrm{~nm}$ using the UV-visible spectrophotometer. The calibration curve was constructed with the help of standard quercetin solution of concentration ranging from the $10-100 \mu \mathrm{g} / \mathrm{mL}$. The total flavonoid content was expressed in terms of the milligram of quercetin equivalent per gram of the dry mass $(\mathrm{mg} \mathrm{QE} / \mathrm{g})^{17}$.

\section{Agar tube dilution protocol for antifungal activity}

$24 \mathrm{mg}$ of crude extract was dissolved in $1 \mathrm{~mL}$ sterile DMSO serving as stock solution. Sabouraud dextrose agar (SDA) was used for the growth of fungus. Media with acidic (pH 5.5-5.6) containing relatively high concentration of glucose or maltose 2 percent was prepared by mixing $32.5 \mathrm{gm} / 500 \mathrm{~mL}$ in distilled water. It was then steamed to dissolve the contents and dispensed as volumes $4 \mathrm{~mL}$ into screw caps tubes. Autoclaved at $121{ }^{\circ} \mathrm{C}$ for $15 \mathrm{~min}$. Tubes were allowed to cool to $50{ }^{\circ} \mathrm{C}$ and non-solidified SDA was loaded with $66.6 \mu \mathrm{L}$ of compound pipetted from the stock solution. The final concentration of $400 \mu \mathrm{g} / \mathrm{mL}$ crude extract was prepared respectively. Tubes then allowed solidifying in slanting position at room temperature. Each tube was inoculated with $4 \mathrm{~mm}$ diameter piece of fungus removed from a sevenday-old culture of fungus. For non-mycelial growth, an agar surface streak was employed. Other media supplemented with DMSO and reference antifungal drugs used as negative and positive control respectively. The tubes were incubated at $27-29{ }^{\circ} \mathrm{C}$ for 3-7 days. Cultures were examined twice weekly during incubation. Growth in the compound amended media was determined by measuring linear growth $(\mathrm{mm})$ and growth inhibition calculated with reference to the negative control ${ }^{18,19}$.

$\%$ Inhibition $=100-\underline{\text { linear growth in test }(\mathrm{mm})} \times 100$

linear growth in control $(\mathrm{mm})$

\section{Results and Discussion}

Phytochemical analysis showed that the methanol extract of Bombax ceiba is rich in secondary metabolites. The results showed that the methanol extract is found as the good source of secondary metabolites such as polyphenols, alkaloids, flavonoids, tannins, carotenoids, saponins, reducing sugars, cardiac glycosides, steroids, terpenoids, and anthraquinone. 


\section{J. Nepal Chem. Soc., Vol. 37, 2017}

Present study carried out to analyze the antioxidant activity of the methanol bark extract of Bombax ceiba. The bark extract is the source of potent antioxidant with the strongest DPPH radical scavenging activity $\left(\mathrm{IC}_{50}=9.37 \pm 0.12 \mu \mathrm{g} / \mathrm{mL}\right.$ ) whereas standard ascorbic acid has $\mathrm{IC}_{50}$ of $45.93 \mu \mathrm{g} / \mathrm{mL}$. The result showed significant amount of total phenolic and flavonoid content in plant extract. The extract of Bombax ceiba, contain high value of phenolic (147.45 $\pm 0.85 \mathrm{mg}$ GAE/g SEM) and flavonoid content (12.54 \pm 0.10 $\mathrm{mg}$ QE/g SEM) exhibited the potent antioxidant activity. The antioxidant activity of plant extract is compared to the results of previously studied plant extracts. The antioxidant capacities in $\mathrm{mg}$ ascorbic acid per gram for plants were Thymus vulgaris $(0.6 \pm 0.3)$, Lavandula vera $(0.6 \pm 0.4)$, Rosmarinus officinalis $(0.5 \pm 0.1)$, Origanum dictamnus $(0.2 \pm 0.2)$, Sideritis cretica $(0.8 \pm 0.1)$, Salvia officinalis $(0.4 \pm 0.1)$ and Origanum vulgare $(0.3 \pm 0.1){ }^{20} \quad$ The result suggested that the bark extract of the Bombax ceiba showed the potent source of antioxidants in comparison to previous results.

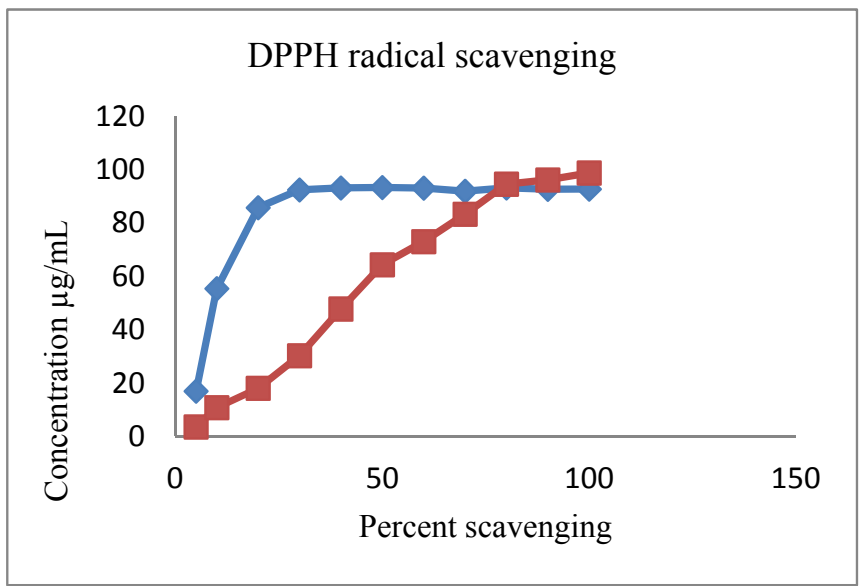

Figure 1: Free radical scavenging activity and concentration of plant sample with standard ascorbic acid

Table 1: DPPH scavenging $\left(I C_{50}\right)$ value, total flavonoid and phenolic content

\begin{tabular}{|l|l|}
\hline Total flavonoid content & $12.54 \pm 0.10 \mathrm{mg}$ QE/g SEM \\
\hline Total phenolic content & $147.45 \pm 0.85 \mathrm{mg} \mathrm{GAE} / \mathrm{g}$ SEM \\
\hline DPPH scavenging $\left(\mathrm{IC}_{50}\right)$ & $9.37 \pm 0.12 \mu \mathrm{g} / \mathrm{mL} \mathrm{SEM}$ \\
\hline
\end{tabular}

Table 2: Antifungal activity of plant extract against different fungi

\begin{tabular}{|c|c|c|c|c|}
\hline \multirow{3}{*}{$\begin{array}{l}\text { Name of fungus } \\
\text { Trichophyton subrum }\end{array}$} & \multicolumn{2}{|c|}{ Linear growth $(\mathrm{mm})$} & \multirow{3}{*}{$\begin{array}{c}\% \\
\text { Inhibition } \\
45\end{array}$} & \multirow{2}{*}{$\begin{array}{c}\text { Std. Drug MIC } \\
\mu \mathrm{g} / \mathrm{mL}\end{array}$} \\
\hline & Sample & Control & & \\
\hline & 55 & 100 & & Miconazole \\
\hline Candida albicans & 100 & 100 & 0 & Miconazole \\
\hline Aspergillus niger & 75 & 100 & 25 & Amphotericin B (20.70) \\
\hline Microsporum canis & 80 & 100 & 20 & Miconazole \\
\hline Fusarium lini & 80 & 100 & 20 & Miconazole \\
\hline Candida glabrata & - & - & - & Miconazole \\
\hline
\end{tabular}

Keys: Concentration of sample $400 \mu \mathrm{g} / \mathrm{mL}$ of DMSO incubation at $27^{\circ} \mathrm{C}\left(28^{\circ} \pm 1^{\circ} \mathrm{C}\right)$, incubation period 7 days (7-10 days). 
The highest antifungal activity with percent inhibition 45 showed by the plant extracts against Trichophyton subrum and Aspergillus niger was recorded at $400 \mu \mathrm{g} / \mathrm{mL}$ concentration, which is nearly to that of the positive control (Miconazole $97.8 \mu \mathrm{g} / \mathrm{mL}$ ), but showed weak inhibition against Microsporum canis and Fusarium lini at $400 \mu \mathrm{g} / \mathrm{mL}$ concentration. The plant extracts did not show any antifungal activity against Candida albicans at the $400 \mu \mathrm{g} / \mathrm{mL}$ concentration used in this study.

This observation agrees with the reports of Leven et al. (1979), Banso and Mann, (2008) on the antifungal properties of plants to the presence of phytoconstituents such as tannins, alkaloids, flavonoids and saponins $s^{21,22}$. The antifungal activity of extracts from Bombax ceiba is probably due to their ability to complex with extracellular and soluble proteins and to complex with bacterial cell walls ${ }^{23}$. The result clearly showed that the bark of the plant may use as the source to isolate the active antifungal agents as well as used to treat the fungal infected patients.

\section{Conclusions}

From this study it is concluded that the plant extracts is the potent source of phytoconstituents and could be used to isolate active compound. DPPH scavenging activity showed that the methanolic extract has potent antioxidant activity. The bark extract showed the potent antioxidant activity with DPPH radical scavenging $\mathrm{IC}_{50}=9.37 \pm 0.12 \mu \mathrm{g} / \mathrm{mL}$ SEM with respect to the standard ascorbic acid of $\mathrm{IC}_{50}$ of 45.93 $\mu \mathrm{g} / \mathrm{mL}$. Phenolic compounds and flavonoids have been reported to be associated with antioxidative action in biological system, acting as scavengers of singlet oxygen and free radicals. The bark extract is the moderate source of total phenolic and flavonoid (147.45 $\pm 0.85 \mathrm{mg} \mathrm{GAE} / \mathrm{g}$ and $12.54 \pm 0.10 \mathrm{mg} \mathrm{QE} / \mathrm{g}$ ) content respectively. The bark extract shows moderate activity against Trichophyton subrum, weak activity against Aspergillus niger, Microsporum canis and Fusarium lini. But, did not show any activity against Candida albicans.

\section{Acknowledgements}

The authors are thankful to Rita Chhetry, National Herbarium and Plant Resources, Ministry of Forests and Soil Conservation, Godawari, for identification of plant. Similarly the authors are grateful to the Central Department of Chemistry and Central Department of Biotechnology, Tribhuvan University for providing some chemicals and laboratory facilities.

\section{References}

1. A. B. Cunningham, Pietermaritzburg, Investigational Report No 29 Institute of Natural Resources, 1988.

2. Y. R. Chanda, The wealth of India Raw materials, New Delhi: CSIR, 1962, 175- 183.

3. Anonymous, The Wealth of India, A dictionary of India raw material, Vol. I, CSIR: New Delhi, 1985, 20-23.

4. E. M. Williamson, Major herbs of Ayurveda, 2002, 261.

5. M. P. Singh and H. panda, Medicinal herbs and their formulations, 2005, 176-178.

6. Rastogi and Mehrotra, Compendium of Indian Medicinal plants, 1990, 2,104.

7. K. R. Joshi, H. P. Devkota and Y. Shoji, Phytochem. Lett., 2014, 7, 26-29. 


\section{J. Nepal Chem. Soc., Vol. 37, 2017}

8. V. Jain, S. K. Vearma, S. K. Katewa, and J. Singh, Res. J. of Med. Plant, 2011, 5(4), 462-470.

9. B. Gandhare, N. Soni and, J. Dhongade, Int. J. of Biomed. Res., 2010, 1(2), 31-36.

10. S. S. Jalalpure and N. B. Gadge, Indian. J. of Pharm. Sci., 2011, 73(3), 306-311.

11. R. Dabur, A. Gupta, T. K. Mandal, D. D. Singh, V. Bajpai, A. M. Gurav and, G. S. Lavekar, Afr. J. of Tradit. Complement and Altern. Med, 2007, 4(3), 313-318.

12. I. Khan, R. S. Surya, D. Surekha, D. G. Srujana and A. Hemasundara, Arch. of Appl. Sci. Res., 2010, 2 (2), 246-250.

13. L. Subedi, S. Timalsena, P. Duwadi, R. Thapa, A. Paudel and K. Parajuli, J. of Tradit. Chinese Med., 2014, 34(5), 584-90.

14. B. Maharjan and B. Baral, Am. J. of Plant Sci., 2013, 4(8), 1660-1665.

15. A. Subedi, M. Shrestha, S. K. Mishra and B. M. Pokharel, J. of Sci. Eng. and Tech. 2012, 8(1), 7380.

16. D. Zhou, J. Ruan, Y. Cai, Z. Xiong, W. Fu and A. Wei, J. of Ethnopharmacol., 2010, 129, 232237.

17. D. Zhou, J. Ruan, Y. Cai, Z. Xiong, W. Fu and A. Wei, J. of Ethnopharmacol., 2010, 129, 232-237.

18. M. I. Choudhary, Z. Parveen, A. Jabbar, I. Ali and Atta-Ur-Rahman, Phytochem., 1995, 40(4), 1243-6.

19. S. Janaki and V. Vijayasekaram, Biomedicine, 1998, 18 (2), 86-9.

20. H. Zorica, P. Hatidza, M. Albina, S. Majda and S. Mirzeta, Eur. J. of Scientific Res, 2009, 28(3), 471-477.

21. M. Leven, D. Venden, A. Berghe, I. Morten, E. Vilientrick and C. Lomweas, Planta Medica, 1979, 36, 311-312.

22. A. Banso and A. Mann, J. of Appl. Biosci., 2008, 12, 665 - 670.

23. H. Tsuchiya, M. Sato, T. Mayazaki, S. Fujiwara, S. Tanigaki, M. Ohyama, T. Tanaka and, M. Linuma, J. of Ethnopharmacol., 1996, 50,27-34. 